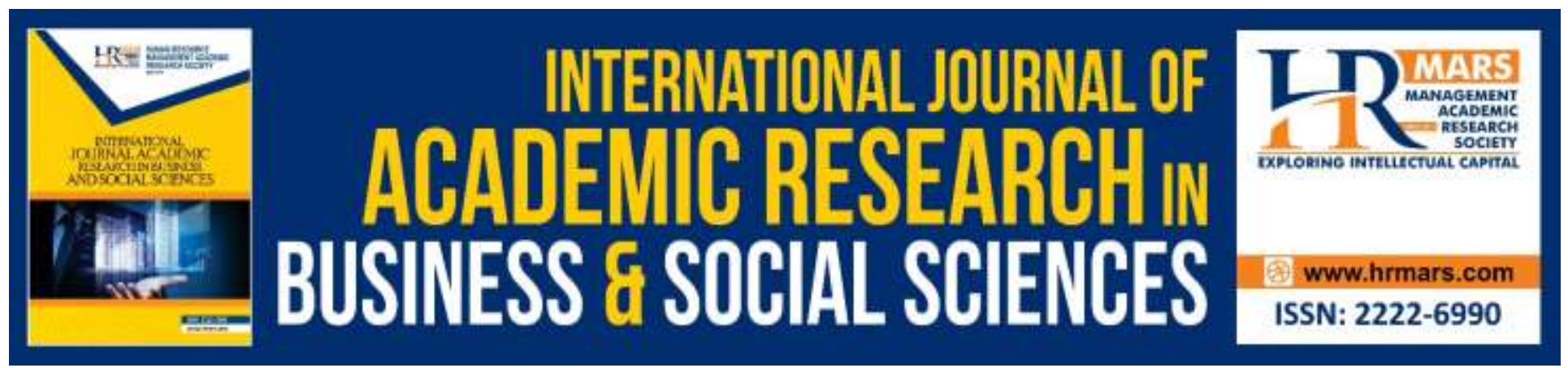

\title{
Mediating Effect of Audit Committee Independence on the Link Between Firms Internal Governance Tunneling from Real Earnings Management
}

Garba Ibrahim, Noorhayati Mansor, Mustapha Nasidi

To Link this Article: http://dx.doi.org/10.6007/IJARBSS/v10-i2/6920

DOI:10.6007/IJARBSS/v10-i2/6920

Received: 20 December 2019, Revised: 10 January 2020, Accepted: 30 January 2020

Published Online: 03 February 2020

In-Text Citation: (Ibrahim et al., 2020)

To Cite this Article: Ibrahim, G., Mansor, N., \& Nasidi, M. (2020). Mediating Effect of Audit Committee Independence on the Link Between Firms Internal Governance Tunneling from Real Earnings Management. International Journal of Academic Research in Business and Social Sciences, 10(2), 195-211.

Copyright: (C) 2020 The Author(s)

Published by Human Resource Management Academic Research Society (www.hrmars.com)

This article is published under the Creative Commons Attribution (CC BY 4.0) license. Anyone may reproduce, distribute, translate and create derivative works of this article (for both commercial and non-commercial purposes), subject to full attribution to the original publication and authors. The full terms of this license may be seen

at: http://creativecommons.org/licences/by/4.0/legalcode

Vol. 10, No. 2, 2020, Pg. 195 - 211

http://hrmars.com/index.php/pages/detail/IJARBSS

JOURNAL HOMEPAGE

Full Terms \& Conditions of access and use can be found at http://hrmars.com/index.php/pages/detail/publication-ethics 


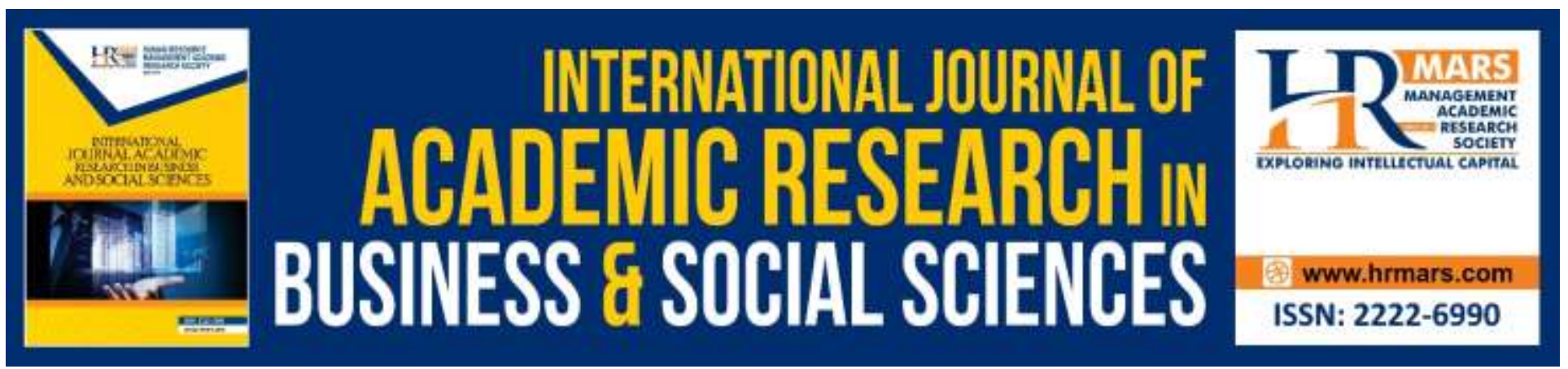

\title{
Mediating Effect of Audit Committee Independence on the Link Between Firms Internal Governance Tunneling from Real Earnings Management
}

\author{
Garba Ibrahim \\ Ph.D. Accounting Student, Faculty of Business and Management, Universiti Sultan Zainal Abidin \\ Terengganu Malaysia \\ E-mail: garbaibraheem92@gmail.com \\ Noorhayati Mansor \\ Professor of Accounting, Faculty of Business and Management, Universiti Sultan Zainal Abidin \\ Terengganu Malaysia \\ E-mail: nhayatimansor@unisza.edu.my \\ Mustapha Nasidi \\ Ph. D Accounting \& Finance, Kano State College of Education \& Preliminary Studies \\ Kano, Nigeria \\ Email: mnasidi_afan@rocketmail.com
}

\begin{abstract}
This paper examines the impact of both, family affiliation and related party transactions tunneling from real activities-based manipulation mediated by audit committee independence based on sample listed non-financial firms Nigeria from 2011 to 2017. The data were obtained from Thomson Reuters DataStream and financial reports of firms. The fixed effects, random effects (GLS), and the generalized method of moments (GMM) were used for panel data regression analysis using the firm internal governance and real earnings management. The findings showed that audit committee independence mediates the relationship between firm internal governance and real earnings management. The results confirm some previous literature that the monitoring role of the affiliated family firms is crucial in mitigating the opportunistic behavior of managers in engaging in real activities manipulation and ensures the earnings quality. However, the analysis of the related party transaction revealed the negative impact on transparency that entrenched managers utilized related parties as a means of tunneling and drained the minority shareholder's interest for the benefit of majority shareholders. In this case, we observed that as family ownership increases, managers
\end{abstract}


INTERNATIONAL JOURNAL OF ACADEMIC RESEARCH IN BUSINESS AND SOCIAL SCIENCES

Vol. 10, No. 2, Feb, 2020, E-ISSN: 2222-6990 @ 2020 HRMARS

engage less in value-destroying behavior because founding family members want to retain transgenerational legacies and care not about short term benefits. Further analysis revealed that leverage has positively impacted on the earnings quality while the firm size was less effective in deterring real earnings manipulation.

\section{Introduction}

A substantial body of research is devoted to comprehending the relationship between affiliated family firms and the quality of financial reporting (Achleitner, Günther, Kaserer, \& Siciliano, 2014; Chen, Gu, Kubota, \& Takehara, 2015; Paiva, Lourenço, \& Curto, 2018). In recent years, researchers have focused on affiliated family businesses due to its remarkable economic benefits and usefulness in various dimensions. These family businesses contributed to almost 70 percent of the global GDP (Almeida-Santos, Andréia, Débora, \& Nayane, 2013). In Nigeria, family firms accounted for nearly 86 percent of businesses ranging from small, medium and large scale enterprises (Hassan \& Ahmed, 2012; PWC, 2018; Sanda, Garba, \& Mikailu, 2011).

Also, these firms face different agency problems emanating between controlling shareholders and minority shareholders called type 11 agency problems. This clash of interest usually comes from the tradeoffs between control, liquidity, and growth that affiliated family firms often face. Moreover, when the controlling shareholder is the firm's founding family, they have motives for retaining control compounded by the desire to preserve trans-generational founder's legacy. These legacies by the controlling shareholders have its-own associated costs, as it may expose the minority shareholders to expropriation called tunneling. Tunneling is the draining of the firm's assets, earnings, and numerous opportunities at the detriment of minority shareholders by the controlling shareholders refer as expropriation (Chen, Cheng, \& Xiao, 2011; Maigoshi et al., 2016). Family affiliated firms utilized related party transactions (RPT) to achieve the attitude mentioned above.

The decision taken by the firm to achieve specific financial reporting objectives can be decoy if it may not reflect the actual position and performance of the firm's operation. Moreover, failure to portray actual firm operation and stand will affect various stakeholders negatively in investment, financing, dividend, liquidity, and many firm decisions (Hassan \& Ibrahim, 2014).

In the past period, there are an increasing number of studies on financial reporting quality, focusing on family firms looking at its relevance. Interestingly, the existing empirical studies offer mixed evidence on this topic.

On the one hand, extant empirical literature revealed that affiliated family firms lead to higher financial reporting quality Songini \& Gnan 2015, and by contrast, some studies documented that affiliated family firms do not lead to quality financial reporting (Paiva et al., 2018).

Apart from that, El-Helaly, Georgiou, \& Lowe, 2018 reports no relationship between related party transactions and earnings management while some other studies by Paiva, Lourenço, \& Branco 2016, Paiva, Lourenço, \& Dias Curto 2018 and Salvato \& Moores, 2010 find a significant positive association between related party transactions and earnings manipulation. However, some studies document a significant negative association between related party transaction and earnings management (Cho 
INTERNATIONAL JOURNAL OF ACADEMIC RESEARCH IN BUSINESS AND SOCIAL SCIENCES Vol. 10, No. 2, Feb, 2020, E-ISSN: 2222-6990 @ 2020 HRMARS

\& Lim, 2018; Lyu, Yuen, \& Zhang, 2017). In light of the inconsistent findings from hitherto empirical studies, this study proposed the following objectives:

i. To examine the effect of affiliated family firm on real earnings management in listed nonfinancial firms Nigeria;

ii. To examine the effect of related party transactions on real earnings management in listed non-financial firms Nigerian;

iii. To examine the mediating effect of audit committee independence on the relationships between firm internal governance tunneling from the real earnings management perspective in listed non-financial firms Nigeria.

\section{Literature Review}

\section{Family Affiliation}

Family Affiliation refers to firms with substantial equity stock of ownership by family members actively involved in the management and governance of the firm. Succeeded in addressing type 1 agency issue between shareholders and management but inclined with type 11 agency problems between majority and minority shareholders refers to tunneling. Family firms dominated businesses globally by either direct or indirect control mechanisms named pyramidal structure. Countries are having the dominance of affiliated family businesses in India, more than $70 \%, 45 \%$ of Italian giant companies, $75 \%$ of US and UK companies, almost 4 million companies in Brazil and Germany, twothird of French market, and the similar figures reported in Sweden, South Africa, Korea, China, and East Asia (Bhaumik, Gregoriou, \& Kumar Bhaumik, 2009; Paiva et al., 2016; Salvato \& Moores, 2010).

\section{The Related Party Transaction}

RPTs have attracted the attention of many stakeholders globally, be it academics, practitioners, investors, regulators, management to mention but a few. RPT is a two-sided sword that plays twin roles in the firm's operations, for both value-generation and value-destroying motives. These benefits comprise minimized transaction costs, prompt decision-making, effective resource generation, and allocation via the internal market within the business group (Maigoshi et al., 2016). On the other hand, detrimental related party transactions are used as a device by firm in extorting minority shareholders as expropriation tool used by majority shareholders and management and the motive behind is for earnings management purposes ( Chen et al., 2011; Sarkar et al., 2013; Shin, Sohn, \& Park, 2019).

\section{Family Affiliation and Real Earnings Management}

Extant empirical evidence provide support to the notion that affiliated family firms exhibit better quality financial reporting and disclosure specifically, earnings management is lower in founding family firms (Achleitner et al., 2014; Cascino, Pugliese, Mussolino, \& Sansone, 2010; Gomez-Mejia et al., 2014; Lyu et al., 2017; Paiva et al., 2016; Sarkar et al., 2013; wan Nadiah \& Mansor, 2018). However, in contrast, some studies argued that affiliated family firms do not lead to quality financial reporting because they care about: meeting market expectations, debts covenant agreement, managerial compensation are used to achieve the earnings targets by controlling shareholders (Ferramosca \& Allegrini, 2018; Songini \& Gnan, 2015; Villalonga, Trujillo, Guzmán, \& Caceres, 2017). 
INTERNATIONAL JOURNAL OF ACADEMIC RESEARCH IN BUSINESS AND SOCIAL SCIENCES Vol. 10, No. 2, Feb, 2020, E-ISSN: 2222-6990 @ 2020 HRMARS

\section{Related Party Transactions and Real Earnings Management}

Hitherto empirical literature documents inconsistent findings regarding related party transactions and earnings management in various settings across the globe. A study conducted by Mita \& Utama, 2017; Yang, Kweh, \& Lin, 2014 documented that related party transactions lead to higher earnings quality. In contrast, other studies reported that related party transactions do not lead to earnings quality in listed non-financial firms by (Gordon \& Elaine Hen, 2017; Kim \& Yoo, 2017; Marchini, Mazza, \& Medioli, 2018; Saleh, Munir, Jaffar, \& Yatim, 2013).

\section{Leverage and Real Earnings Management}

Levered firms are assumed to affect the quality of earnings and deterred opportunistic managerial behavior. Though this evidence is in congruence to the proposition that highly levered firms are likely to attract stronger monitoring from debt holders, and thus, may not be able to engage in earnings manipulation (Becker, Defond, \& California, 1998). While on one side, it is documented that highly geared firms are more likely to engage in earnings management activities to avoid debt covenant violations (García-s, 2016; Prencipe, Bar-Yosef \& Dekker, 2014).

\section{Firm Size and Real Earnings Management}

The larger firms are assumed to have impacted on the earnings quality due to some reasons. First, effective internal control systems, in comparison to smaller ones, can lead to decreasing the likelihood of manipulating earnings by management(Choi, Sohn, \& Yuen, 2018; Habbash, 2010). Second, larger firms are getting better audit services from established audit firms due to larger operating budgets, which in turn could help prevent earnings manipulation. Thirdly, the desire to maintain a reputation by the management can lead to good earnings quality and restrain manipulative attitude. Despite the significant role plays by the larger firms in enhancing the quality earnings larger firms compromise the earnings quality due to: capital market pressure, better bargaining power with the auditors and strong management which may override the internal control system (Atu, Osaretin, Manager, \& Osaretin, 2016; Tesfaye Lemma, Minga Negash Mlilo, 2013).

\section{Underpinning Theories}

Agency theory focused on how management of firms can be highly ethical in operation and producing what is true and fair in curtailing opportunistic attitude, while institutional theory focused on how firm incorporate social culture and meet the demand of social, environmental, legal and political environs for long term survival of the firm (Habbash \& Alghamdi, 2017; Jensen \& Meckling, 1998; Mudambi \& Pedersen, 2007). However, agency theory alone does not cover corporate governance fully; combining the agency theory (shareholders model) with institution theory (stakeholder's model) establishes a foundation that redefines the model of corporate governance to achieve better firm performance, better monitoring and quality financial reports (Ibrahim, Bello, \& Kargi, 2016; Mallin, 2008). So this study will apply the two theories to under pin the research

\section{Methodology}

The study utilized annual panel data from Thomson Reuters DataStream and firm financial reports for 2009-2017, but 2009 and 2010 were used for lagging in the dependent variable derivation. The study used 335 listed non-financial firms for data analysis using two-step GMM regression. Firms in 
the financial, mining and regulated industries were excluded due to different accrual choices and valuation processes. The real earnings management component from abnormal cash flow from the operation, abnormal production cost, and abnormal discretionary expenses were used to proxy earnings quality (Al-shattarat, 2017; Dechow \& Skinner, 2000; Haji-Abdullah \& Wan-Hussin, 2015). The independent variables of the study are (i) family affiliation and (ii) related party transactions. Family affiliation is measured by the percentage of common stock ownership by founding family members (Achleitner et al., 2014; Guo \& Ma, 2015; Tian, Yang, \& Yu, 2018). Also, related party transactions are measured by the natural logarithm of annual transaction value and were derived from firms' financial reports (Marchini et al., 2018; Shin et al., 2019). The study further used control variables that previously shown to be effective in enhancing the earnings quality. The control variables are firm size measured as the natural logarithm of total assets (Andres, 2008; Cheng, 2014; Songini \& Gnan, 2015). Besides, the study measured leverage as debts to total assets ratio (Kim \& Yoo, 2017; D. Wang, 2006).

Model Specification

Stage one, cross-sectional regression was run of cash flow from operation divided by the prior year total assets will be regressed against current year sales by lagged total assets plus the change in sales divided by previous year total assets. The regression residuals are the abnormal cash flow from the operation (Ibrahim et al., 2016).

$\frac{C F O_{t}}{T a_{t-1}}=\alpha 0+\alpha 1\left[\frac{1}{T a_{t-1}}\right]+K_{1}\left[\frac{S t}{T a_{t-1}}\right]+K_{2}\left[\frac{\Delta S t}{T a_{t-1}}\right]+\varepsilon_{i t} \quad$ Equation 1

Stage two, further cross-sectional regression was also run of summation of discretionary expenses (advertising, research and development, and selling, general and admin expenditure) divided by preceding year total assets against current year sales divided by previous year total assets. The regression residuals stand as abnormal discretionary expenses.

$\frac{\operatorname{DISEXP}_{t}}{T a_{t-1}}=\alpha 0+\alpha 1+\left[\frac{1}{T a_{t-1}}\right]+K_{1}\left[\frac{S t}{T a_{t-1}}\right]+\varepsilon_{i t} \quad$ Equation 2

Stage three, moreover, cross-sectional regression was also run of production cost divided by the lagged total against current year sales scaled by total assets plus the change of sales by prior year total assets, plus also contemporaneous sales divided by preceding year total assets. The residuals from the model stand abnormal production costs (Abubakar, 2016; Haji-Abdullah \& Wan-Hussin, 2015).

$\frac{P R O D_{t}}{T a_{t-1}}=\alpha 0+\alpha 1+\left[\frac{1}{T a_{t-1}}\right]+K_{1}\left[\frac{S t}{T a_{t-1}}\right]+K_{2}\left[\frac{\Delta S t}{T a_{t-1}}\right]+K_{3}\left[\frac{\Delta S t}{T a_{t-1}}\right]+\varepsilon_{i t} \quad$ Equation 3

The components were computed separately, and applied them as follows: abnormal cash flow to be multiplied by (-1) as firms that are more likely to engage in real activities manipulations normally have lower cash flow from operation. Abnormal discretionary expenditures multiplied by (-1) so that higher value signposts that it is more likely that firm reduces discretionary expenditures and the abnormal production cost was multiplied by $(+1)$. The study used the combined residuals as REM (Cohen \& Zarowin, 2008; Duan, Yeh, \& Dowe, 2018; Haga, Siekkinen, \& Sundvik, 2015; Tesfaye Lemma, Minga Negash Mlilo, 2013).

\section{Mediation Analysis}

Several steps are needed preceding testing the mediation effect 
INTERNATIONAL JOURNAL OF ACADEMIC RESEARCH IN BUSINESS AND SOCIAL SCIENCES

Vol. 10, No. 2, Feb, 2020, E-ISSN: 2222-6990 ¿ 2020 HRMARS

The study proposed three dependency models: firstly, regressed the dependent variable against the independent variable; secondly, regressed the mediator variable against the independent variable; and thirdly, regressed the dependent variable against the independent, mediator and control variables (Baron \& Kenny, 1986; García-s, 2016; Ishak, Aziah, \& Manaf, 2013; Li, 2011).

Mediation models are given as follows:

Two-step GMM

Regression one

REMit $=\beta 0+\beta 1$ REMit $(-1)+\beta 2 F M A F L i t+\beta 3 R P T i t+\beta 4$ LEVit $+\beta 5 F S Z 4 i t+\varepsilon i t$

Model 1

Regression two

ACIit $=\beta 0+\beta 1$ ACIit $(-1)+\beta 2 F M A F L i t+\beta 3 R P T i t+\beta 4 L E V i t+\beta 5 F S Z 4 i t+$ Eit Model 2

Regression three

REMit $=\beta 0+\beta 1$ REMit $(-) 1+\beta 2 F M A F L i t+\beta 3$ RPTit $+\beta 4$ ACIit $+\beta 5$ LEVit $+\beta 6 F S Z+$ Eit Model 3

Table 4.1 Unit root Test

\begin{tabular}{|l|c|c|c|c|}
\hline & \multicolumn{2}{|c|}{ Fisher } & \multicolumn{2}{c|}{ Harris-Travalis } \\
\hline Variables & At level & First difference & At level & $\begin{array}{c}\text { First } \\
\text { difference }\end{array}$ \\
\hline REM & $580.35^{*}$ & $885.66^{*}$ & -16.355 & -12.865 \\
& $(0.000)$ & $(0.000)$ & $(0.000)$ & $(0.000)$ \\
\hline Family & 294.77 & 762.93 & -3.032 & -4.4520 \\
affiliation & $(0.000)$ & $(0.000)$ & $(0.005)$ & $(0.002)$ \\
\hline Related Party & 280.87 & 539.26 & -3.848 & -4.559 \\
& $(0.000)$ & $(0.000)$ & $(0.000)$ & $(0.000)$ \\
\hline Leverage & 203.27 & 676.126 & -3.696 & -3.1263 \\
& $(0.000)$ & $(0.000)$ & $(0.000)$ & $(0.009)$ \\
\hline Firm size & 203.64 & 578.003 & -3.128 & -2.9322 \\
& $(0.000)$ & $(0.000)$ & $(0.004)$ & $(0.025)$ \\
\hline
\end{tabular}

The study used micro- panel data in which the cross-sectional dimension far exceeded the time dimension. The study utilized Fisher type and Harris Travaliz for unit root test. It has conducted a panel unit root test individually for predictors, outcome, mediator, and the control variables for the period under study. The data were stationary at the level and first difference, as depicted from the unit root table. Moreover, the mixed stationarity of the data permits us to use the system GMM (Baltagi, 2005; Oino \& Ukaegbu, 2015). 
INTERNATIONAL JOURNAL OF ACADEMIC RESEARCH IN BUSINESS AND SOCIAL SCIENCES Vol. 10, No. 2, Feb, 2020, E-ISSN: 2222-6990 @ 2020 HRMARS

Univariate Analyses

\begin{tabular}{|l|c|c|c|c|l|}
\hline \multicolumn{1}{|c|}{ Variable } & Mean & Std. deviation & Skewness & Kurtosis & VIF \\
\hline REM & 8.4224 & 7.8318 & -2.5261 & 11.2929 & 2.25 \\
\hline FMAFL & 2.8227 & 5.7192 & -1.0295 & 3.0285 & 1.00 \\
\hline$R P T$ & 4.7534 & 2.5475 & 1.0578 & 2.6099 & 1.25 \\
\hline LV & 0.5924 & 0.4906 & -5.4036 & 13.1637 & 1.62 \\
& & & & & \\
FS & 17.359 & 0.3617 & 0.9246 & 3.9343 & 1.01 \\
\hline
\end{tabular}

The descriptive statistics for the variables in the study are presented in Table 2, of affiliated family firms, related party transactions, and real earnings management. The mean value of the real earnings management index of (8.4224) implies that, on average, these firms engaged in real activities manipulation in listed non-financial firms, Nigeria. Regarding the family affiliation, the table reveals that family firms' impact on real earnings manipulation to promote firms' ethical behavior and related party transactions are also affected by real earnings management in listed non-financial firms Nigeria. Concerning the control variables, for example, the average leverage is 0.5972 , indicating that listed non-financial firms are highly levered and have an impact on the earnings quality. Moreover, the average firm size is 17.359 showing that larger firms also engaged in real earnings manipulation in listed non-financial firms, Nigeria. The standard deviation is consistently less than the mean except for family affiliation due to sporadic share ownership. Furthermore, the study used variance inflation factor to assess the multicollinearity among the regressors, and the table reveals that they are consistently less than 10, indicating absence of harmful collinearity problem (Adamu, Ishak, \& Chandren, 2017; Gujarati, 2004; Ibrahim et al., 2016).

Table 4.3 Bivariate Analysis

\begin{tabular}{|c|r|r|r|r|r||}
\hline Correlation Matrix & & & & \\
\hline Probability & REM & FMAFL & RPT & LV & FS \\
\hline REM & 1.000000 & & & & \\
\hline & ---- & & & & \\
\hline FMAFL & $-0.1542 * *$ & 1.000000 & & & \\
\hline & 0.0026 & ----- & & & \\
\hline & & & & & \\
\hline RPT & $-0.0272 *$ & $0.1475^{*}$ & 1.000000 & & \\
\hline & 0.6752 & 0.0014 & ---- & & \\
\hline & & & & & \\
\hline LV & -0.0298 & $0.5769 *$ & $0.1434 *$ & 1.000000 & \\
\hline & 0.5202 & 0.3200 & 0.0018 & ----- & \\
\hline FS & & & & & \\
\hline & 0.0103 & $0.1399 *$ & 0.0783 & 0.0452 & 1.000000 \\
\hline & 0.5247 & 0.0024 & 0.0904 & 0.3289 & \\
\hline
\end{tabular}

Notes: ${ }^{* * *}$ and ${ }^{* *}$ denotes significant at $1 \%, 5 \% \& 10 \%$ levels respectively 
INTERNATIONAL JOURNAL OF ACADEMIC RESEARCH IN BUSINESS AND SOCIAL SCIENCES Vol. 10, No. 2, Feb, 2020, E-ISSN: 2222-6990 @ 2020 HRMARS

The correlation matrix revealed that family affiliation, related party transactions, and leverage are inversely correlated with real earnings management. The study further revealed that firm size is positively associated with real earnings management in listed non-financial firms, Nigeria.

The table reveals that affiliated family firms are negatively related to real earnings management and significant at $5 \%$ level. The table further reveals that related party transaction is inversely correlated with real earnings management and significant at $10 \%$ level, while related party transaction is positively related with family affiliation and significant at the $10 \%$ level. Moreover, the table has shown that leverage is negatively associated with real earnings management and not significant, while the table reveals that leverage is positively correlated with affiliated family firms and related party transactions and significant at $10 \%$ level, respectively. Further, the table reveals that firm size is positively related to real earnings management, affiliated family firms, related party transaction, and leverage are positively related but not significant.

The study conducted a Hausman test and choose between fixed and random effects, and the outcomes showed that the t-statistics were insignificant that suggest the use of random effect regression (Hassan \& Bello, 2013; Mustapha, Nik, Rashid, Lateef, \& Bala, 2019; Torres-reyna, 2007).

Table 4.4 Multivariate Analysis of Two-Step Panel GMM Regressions of Family Affiliation, RPT on REM

\begin{tabular}{|c|c|c|c|c|}
\hline Variables & $\begin{array}{l}\text { Expected } \\
\text { sign }\end{array}$ & Model 1 & Model2 & Model3 \\
\hline REM & & $\begin{array}{c}-0.7092 * * * \\
(0.009)\end{array}$ & & $\begin{array}{c}-0.7110^{* * *} \\
0.0086 \\
\end{array}$ \\
\hline$A C$ & - & - & $\begin{array}{c}0.3888 * * * \\
(0.0202)\end{array}$ & $\begin{array}{c}-0.1382 * * * \\
0.0125\end{array}$ \\
\hline FMAFL & - & $\begin{array}{l}-0.2664 \\
(0.2340)\end{array}$ & $\begin{array}{l}-0.8332 * \\
(0.4402)\end{array}$ & $\begin{array}{c}-0.1923 * * \\
(0.080)\end{array}$ \\
\hline RPT & - & $\begin{array}{l}-0.4511^{*} \\
(0.2511)\end{array}$ & $\begin{array}{c}-0.8503^{* *} \\
(0.3504)\end{array}$ & $\begin{array}{c}0.3628 * * * \\
0.1124\end{array}$ \\
\hline LV & - & $\begin{array}{c}0.3102 * * * \\
(0.0399)\end{array}$ & $\begin{array}{c}-0.3869 * * * \\
(0.0415)\end{array}$ & $\begin{array}{c}-0.2599 * \\
0.150\end{array}$ \\
\hline FS & - & $\begin{array}{c}-0.7893^{* *} \\
(0.3280)\end{array}$ & $\begin{array}{c}0.6652 * * * \\
(0.0563)\end{array}$ & $\begin{array}{c}0.6947^{* *} \\
0.0280\end{array}$ \\
\hline $\begin{array}{l}\text { No. } \\
\text { observation }\end{array}$ & & 335 & 335 & 335 \\
\hline Probability & & 0.000 & 0.000 & 0.000 \\
\hline AR1 & & 0.225 & 0.020 & 0.270 \\
\hline AR2 & & 0.325 & 0.318 & 0.295 \\
\hline
\end{tabular}


INTERNATIONAL JOURNAL OF ACADEMIC RESEARCH IN BUSINESS AND SOCIAL SCIENCES Vol. 10, No. 2, Feb, 2020, E-ISSN: 2222-6990 @ 2020 HRMARS

\begin{tabular}{|l|c|c|c|}
\hline $\begin{array}{l}\text { Sargan } \\
\text { statistics }\end{array}$ & 0.000 & 0.000 & 0.000 \\
\hline $\begin{array}{l}\text { Hansen } \\
\text { statistics }\end{array}$ & 0.319 & 0.244 & 0.311 \\
\hline $\begin{array}{l}\text { no of } \\
\text { instruments }\end{array}$ & 25 & 54 & 30 \\
\hline no of group & 67 & 67 & 67 \\
\hline
\end{tabular}

Notes: $* * *, * *$, and $*$ significant at $1 \%, 5 \%$ \& $10 \%$ levels respectively, and the figures in parenthesis signify standard error of the estimates, and the upper ones are coefficients from GMM regression. The study fulfilled some conditions preceding the use of the system generalized method of moments (GMM). The study used annual balance panel data, and the number of cross-sections far exceeded the time dimension. The study further specified the dynamic model by including the lagged dependent variable among the predictors. Endogeneity and heterogeneity were accounted for by the use of two-step GMM regression to address firm effect and time effect and avoid biasing the results. The GMM outcome revealed that the numbers of instruments were less than the number of groups, and the F- statistics are jointly significant. Besides, the AR2 second-order autocorrelation was not significant, as illustrated in table 4. The table further revealed that Hansen's statistics across the models were all not significant. The dynamic dependent variable and the regressors are all statistically significant, as reflected in the table (Baltagi, 2010; Hoechle, 2010; Saona \& Muro, 2018; Wang, Iglesias, \& Wooldridge, 2013).

\section{Model 1}

The table reveals that real earnings management is significant at $1 \%$ level depicted by the $p$-value (0.000). The table further shows that affiliated family firms are inversely related to real earnings management but not significant. Moreover, related party transactions are negatively related to real earnings management and significant at the $10 \%$ level. The study shows that leverage is positively associated with real earnings management and significant at $1 \%$ level. Firm size is negatively related to real earnings management and significant at $5 \%$ level.

\section{Model 2}

The table reveals that audit committee independence is significant at $1 \%$ level depicted by the $p$ value (0.000). It further reported that affiliated family firms and related party transactions are negatively correlated with audit committee independence and significant at $10 \%$ and $5 \%$ level, respectively. The table further shows that leverage and firm size are negatively and positively associated with audit committee independence and significant at $1 \%$ level, respectively.

\section{Model 3}

The table reveals that real earnings management is statistically significant at the $1 \%$ level depicted by the $p$-value (0.000). The findings further buttress that audit committee independence is negatively correlated with real earnings management and significant at $1 \%$ level. The study further reveals that affiliated family firms are inversely correlated with real earnings management and significant at $5 \%$ level. These indicates that affiliated family firms restrain activity-based manipulation by the listed non-financial firms in Nigeria and do not trade off their long term value for short term benefits. These 
INTERNATIONAL JOURNAL OF ACADEMIC RESEARCH IN BUSINESS AND SOCIAL SCIENCES Vol. 10, No. 2, Feb, 2020, E-ISSN: 2222-6990 @ 2020 HRMARS

findings are concord with the findings of (Bonacchi, Massimiliano Fabrizio, 2017; Tian et al., 2018; wan Nadiah \& Mansor, 2018), which reveals that family affiliation is negatively correlated with real earnings management in Italy, Malaysia and Chinese's study. However, the findings are not in harmony with (Paiva et al., 2018) Spanish study unless if moderated by analysts' coverage. The study further revealed that related party transaction is positively associated with real earnings management and significant at $1 \%$ level the findings is in harmony with (Gordon \& Elaine Hen, 2017; Saleh et al., 2013), American and Malaysian study while the findings are not in line with the study of Mita \& Utama, 2017 an Indonesian study.

Furthermore, the study reveals that leverage and firm size are inversely and positively related to real earnings management and significant at $10 \%$ and $5 \%$ level, respectively. Affiliated family firms were initially not significant but now significant at $5 \%$. Related party transaction was initially significant at $10 \%$ but now significant at $1 \%$ level. Moreover, the leverage was initially significant at $1 \%$ but changed to a $10 \%$ level of significance. Because of that, this study buttress that introducing the mediating variable audit committee independence mediates the relationship between firm internal governance and real earnings management.

\section{Robustness Test of the Findings}

This study, as a further robustness test of the findings, the two-stage GMM system approach used as the main method, and the Arellano and Bond (1991) method used as a second-order method, and the reliability of the estimates depends critically on the nonexistence of second-order serial correlation and the validity of the instruments. Therefore, the $\operatorname{AR}(2)$ statistic is used to measure the second-order serial correlation, on the one hand, and the Hansen (1982) contrast of over-identified restrictions is used to check if the instruments are exogenously determined, on the other hand. Additionally, we used the Wald test of joint significance for all independent variables and tested the potential multicollinearity problems through the Variance Inflation Factor (VIF). As further robustness checks of our major findings, we used robust standard error as a sand witch estimator to address the heteroscedasticity of the data

\section{Conclusion, Contribution and Direction for Future Studies}

In this study, we use a large sample of Nigerian listed non-financial firms to examine the mediating effect of audit committee independence on the relationship between affiliated family firms, related party transactions, and real earnings management using 335 firm-year observations. This study used random and fixed effect GLS and two-step GMM regression for panel data analysis. The study's findings revealed that audit committee independence mediates the relationship between affiliated family firms, related party transactions, and real earnings management in listed non-financial firms Nigeria. The study further revealed that affiliated family firms positively impacted the earnings quality and restrained manipulative behavior in listed non-financial firms, Nigeria. Moreover, this study also reports that related party transactions negatively impacted the earnings quality and did not lead to constraining the manipulative attitude by the management of listed non-financial firms, Nigeria. The study also documented that leverage positively impacted on the earnings quality and deterred activity-based manipulation while the study further revealed that firm size does not lead to earnings quality and indicates that large firms also engaged in activity-based earnings management likely due 
INTERNATIONAL JOURNAL OF ACADEMIC RESEARCH IN BUSINESS AND SOCIAL SCIENCES

Vol. 10, No. 2, Feb, 2020, E-ISSN: 2222-6990 @ 2020 HRMARS

to capital market pressure, higher operating budget which may induce the auditors to collaborate and compromise the audit quality.

\section{Recommendation}

Firstly, in order to improve the monitoring capabilities of corporate board, decision control \& management and to reduce type i agency problems, the affiliated family firms should be enhance by ameliorating the proportion of share owned and role play by founding family members in governance in order to curtail opportunistic attitude of value-destroying behavior that may affect the chances to continue as a going concern if proper attention has not been taken to deter the problem.

Secondly, to protect the interest of minority shareholders, listed non-financial firms should abstain from engaging in detrimental related party transaction that may lead to expropriating the firm's assets, earnings and other benefits at the expenses of minority shareholders. Listed non-financial firms should be utilizing value-generated related party transactions to enhance firm's earnings, firm's value and deter opportunistic attitude in Nigeria.

\section{Frontier for Future Research}

a) The relationship between firm internal and external monitoring mechanism can be extended to other sector of the economy such as financial service industries, ICT, industries, services and natural resources industries sector requires research effort as they are not covered in this study.

b) In addition same research can be conducted by using concentrated ownership, foreign ownership, and government ownership, cross-listing or a pyramidal ownership structure, auditor independence, joint- audits, liquidity, sales growth, age, intangible assets, complexity of business and industry type.

c) Furthermore, another study can use the derivatives from oil and gas companies to smooth their earnings target.

\section{Contribution}

The contribution of the study can be appreciated from theoretical, methodological and practical perspectives and will be of interest and benefits to firms and the global economy at large. Theoretically, this study contributes to the literature by combining both the agency and institutional theories to enhance firm governance and ameliorate the earnings quality (Durisin \& Puzone, 2009; Mallin, 2008).

Methodological this study used composite real earnings management index for listed non-financial firms Nigeria utilizing two-step system GMM regression and used independent audit committee as mediator which other studies have not yet considered.

Practical contribution, the study will also aid to corroborate the scholars' view about the role of monitoring and ameliorating the reliability of the reported earnings to restore investors' past fading confidence in financial statements. Serve as index for evaluating the managerial compensation and to decide when to buy, sell or hold firm securities based on their decoy or actual earnings figures reported. 
INTERNATIONAL JOURNAL OF ACADEMIC RESEARCH IN BUSINESS AND SOCIAL SCIENCES

Vol. 10, No. 2, Feb, 2020, E-ISSN: 2222-6990 @ 2020 HRMARS

\section{References}

Abubakar, M. (2016). Effect of Audit Quality and Corporate Governance on Real Activities Manipulation in Nigerian Banks. Proceedings of the 6th Economic \& Finance Conference, (September), 1-26. https://doi.org/10.20472/EFC.2016.006.001

Achleitner, A. K., Günther, N., Kaserer, C., \& Siciliano, G. (2014). Real Earnings Management and Accrual-based Earnings Management in Family Firms. European Accounting Review, 23(3), 431461. https://doi.org/10.1080/09638180.2014.895620

Adamu, A. I., Ishak, R. B., \& Chandren, S. A. (2017). The Effect of Board Attributes on Real Earnings Management in Nigerian Financial Institutions. Journal of Accounting, Business and Finance Research, 1(1), 76-83. https://doi.org/10.20448/2002.11.76.83

Al-shattarat, B. (2017). Real Earnings Management Activities, Meeting Earnings Benchmarks and Future Performance: UK evidence, University of Plymouth PhD Theses available at https://pearl.plymouth.ac.uk

Almeida-Santos, S., Andréia, C. D., Débora, G. M., \& Nayane, T. K. (2013). Influence of family control in the practice of earnings management. Management Research: Journal of the Iberoamerican Academy of Management, 11(1), 77-99. https://doi.org/10.1108/1536-541311318080

Andres, C. (2008). Large shareholders and firm performance An empirical examination of foundingfamily ownership is, 14, 431-445. https://doi.org/10.1016/j.jcorp

Atu, O. E., Osaretin, K., Manager, A., \& Osaretin, C. (2016). Determinants of Earnings Management in Nigerian Quoted Companies. Igbinedion University Journal of Accounting, 1(1), 118-133. Retrieved from https://www.iuokada.edu.ng/journals/791F85C39126667

Baltagi, B. H. (2005). Econometric Analysis of Panel Data (Third edit). West Sussex, England: John Wiley \& Sons, Ltd.

Baltagi, B. H. (2010). Unbalanced Panel Data Models. Introduction to Unbalanced Panel Data Models with Stata, 1-19.

Baron, R. M., \& Kenny, D. A. (1986). The Moderator-Mediator Variable Distinction in Social Psychological Research : Conceptual, Strategic, and Statistical Considerations, 51(6), 11731182.

Becker, C. L., Defond, M. L., \& California, S. (1998). The Effect of Audit Quality on Earnings Management *, 15(1), 1-24.

Bhaumik, S., Gregoriou, A., \& Kumar Bhaumik, S. (2009). Family Ownership, Tunneling and Earnings Management: A review of the literature http://ssrn.com/abstract=1488917

Bonacchi, Massimiliano Fabrizio, C. P. Z. (2017). Parent use of Subsidiary to push down Earnings management. ARPN Journal of Engineering and Applied Sciences, 12(10), 3218-3221. https://doi.org/10.1111/ijlh.12426

Cascino, S., Pugliese, A., Mussolino, D., \& Sansone, C. (2010). The Influence of Family Ownership on the Quality of Accounting Information. Family Business Review, 23(3), 246-265. https://doi.org/10.1177/0894486510374302

Chen, J., Cheng, P., \& Xiao, X. (2011). Related party transactions as a source of earnings management. Applied Financial Economics, 21(3), 165-181. https://doi.org/10.1080/09603107.2010.528361

Chen, T.-Y., Gu, Z., Kubota, K., \& Takehara, H. (2015). Accrual-Based and Real Activities Based Earnings Management Behavior of Family Firms in Japan. The Japanese Accounting Review, 5(2015), 2147. https://doi.org/10.11640/tjar.5.2015.02 
INTERNATIONAL JOURNAL OF ACADEMIC RESEARCH IN BUSINESS AND SOCIAL SCIENCES Vol. 10, No. 2, Feb, 2020, E-ISSN: 2222-6990 @ 2020 HRMARS

Cheng, Q. (2014). Family firm research - A review q. China Journal of Accounting Research. https://doi.org/10.1016/j.cjar.2014.03.002

Cho, S., \& Lim, K. M. (2018). Tunneling by Related-party Transactions: Evidence from Korean Conglomerates. Asian Economic Journal, 32(2), 147-164. https://doi.org/10.1111/asej.12146

Choi, A., Sohn, B. C., \& Yuen, D. (2018). Do auditors care about real earnings management in their audit fee decisions? Asia-Pacific Journal of Accounting and Economics, 25(1-2), 21-41. https://doi.org/10.1080/16081625.2016.1231580

Cohen, D. A., \& Zarowin, P. (2008). Economic Consequences of Real and Accrual-Based Earnings Management Activities. Working Paper, New York University.

Dechow, P. M., \& Skinner, D. J. (2000). Earnings Management : Reconciling the Views of Accounting Academics, Practitioners, and Regulators, 14(2), 235-250.

Duan, Y., Yeh, C., \& Dowe, D. L. (2018). Accounting Results Modelling with Neural Networks : The Case of an International Oil and Gas Company. Springer International Publishing. https://doi.org/10.1007/978-3-030-04179-3

Durisin, B., \& Puzone, F. (2009). Maturation of corporate governance research, 1993-2007: An assessment. Corporate Governance: An International Review, 17(3), 266-291. https://doi.org/10.1111/j.1467-8683.2009.00739

El-Helaly, M., Georgiou, I., \& Lowe, A. D. (2018). The interplay between related party transactions and earnings management: The role of audit quality. Journal of International Accounting, Auditing and Taxation. https://doi.org/10.1016/j.intaccaudtax.2018.07.003

Ferramosca, S., \& Allegrini, M. (2018). The complex role of family involvement in earnings management. Journal of Family Business Strategy, 9(2), 128-141. https://doi.org/10.1016/j.jfbs.2018.01.001

García-s, I. (2016). The mediating effect of ethical codes on the link between family fi rms and their social performance. https://doi.org/10.1016/j.Irp.2016.11.007

Gomez-Mejia, L. R., Campbell, J. T., Martin, G., Hoskisson, R. E., Makri, M., \& Sirmon, D. G. (2014). Socioemotional Wealth as a Mixed Gamble: Revisiting Family Firm R\&D Investments With the Behavioral Agency Model. Entrepreneurship: Theory and Practice, 38(6), 1351-1374. https://doi.org/10.1111/etap.12083

Gordon, E. A., \& Elaine Hen. (2017). Related Party Transactions and Earnings Management, available at https://doi.org/10.2139/ssrn.612234

Gujarati, D. (2004). Basic Econometrics (fourth edition). Chicago, USA: The McGraw-Hill Companies.

Guo, F., \& Ma, S. (2015). Ownership Characteristics and Earnings Management in China. Chinese Economy, 48(5), 372-395. https://doi.org/10.1080/10971475.2015.1067086

Habbash, M. (2010). The Effectiveness of Corporate Governance and External Audit on Constraining Earnings Management Practice in the UK. PhD Thesis, 351. https://doi.org/10.1007/s13398-0140173-7.2

Habbash, M., \& Alghamdi, S. (2017). Audit quality and earnings management in less developed economies : the case of Saudi Arabia. Journal of Management \& Governance, 21(2), 351-373. https://doi.org/10.1007/s10997-016-9347-3

Haga, J., Siekkinen, J., \& Sundvik, D. (2015). A neural network approach to measure real activities manipulation. Expert Systems with Applications, 42(5), 2313-2322.

https://doi.org/10.1016/j.eswa.2014.10.047 
INTERNATIONAL JOURNAL OF ACADEMIC RESEARCH IN BUSINESS AND SOCIAL SCIENCES Vol. 10, No. 2, Feb, 2020, E-ISSN: 2222-6990 @ 2020 HRMARS

Haji-Abdullah, N. M., \& Wan-Hussin, W. N. (2015). Related party transactions, audit committees and real earnings management: The moderating impact of family ownership. Advanced Science Letters, 21(6), 2033-2037. https://doi.org/10.1166/asl.2015.6195

Hassan, S. U., \& Ahmed, A. (2012). Ownership Structure and Oppurtunistic Accounting : A case of listed food and Beverages ISSN : 2249-5894, 2(7), 236-256.

Hassan, S. U., \& Bello, A. (2013). Firm Characteristics and Financial Reporting Quality of Listed manufacturing firms in Nigeria. International Journal of Accounting, Banking and Management, 1(6), 47-63.

Hassan, S. U., \& Ibrahim, G. (2014). Governance Attributes and Real Activities Manipulation of Listed Manufacturing Firms in Nigeria. International Journal of Accounting and Taxation, 2(1), 37-62.

Hoechle, D. (2010). Robust Standard Errors for Panel Regressions with Cross-Sectional Dependence, (ii), 1-31.

Ibrahim, G., Bello, A., \& Kargi, H. S. (2016). Audit Committee Attributes and Real Activities Manipulation of listed manufacturing firms in Nigeria. International Journal of Development and Sustainability, 4(9r), 963-976.

Ishak, Z., Aziah, N., \& Manaf, A. (2013). Board Effectiveness and Company Performance : Assessing the Mediating Role, 14(2), 319-338.

Jensen, M. C., \& Meckling, W. H. (1998). Theory of the Firm: Managerial Behavior, Agency Costs and Ownership Structure. Ssrn. https://doi.org/10.2139/ssrn.94043

Kim, S., \& Yoo, J. (2017). Does R\&D expenditure with heavy related party transactions harm firm value? Journal of Sustainability (Switzerland), 9(7), 1-15. https://doi.org/10.3390/su9071216

Li, S. D. (2011). Testing Mediation Using Multiple Regression and Structural Equation Modeling Analyses in Secondary Data. https://doi.org/10.1177/0193841X11412069

Lyu, C., Yuen, D. C. Y., \& Zhang, X. (2017). Individualist-collectivist culture, ownership concentration and earnings quality*. Asia-Pacific Journal of Accounting and Economics, 24(1-2), 23-42. https://doi.org/10.1080/16081625.2015.1129281

Maigoshi, Z., Latif, R. A., \& Kamardin, H. (2016). Earnings Management : A Case of Related Party Transactions. International Journal of Economics and Financial Issues,

Mallin, C. (2008). Institutional shareholders: their role in the shaping of corporate governance. Review Literature And Arts Of The Americas, 1(1), 97-105.

Marchini, P. L., Mazza, T., \& Medioli, A. (2018). Related party transactions, corporate governance and earnings management. Corporate Governance (Bingley). https://doi.org/10.1108/CG-11-20170271

Mita, A. F., \& Utama, S. (2017). The Influence of Corporate Governance Mechanism on the Relationship between Related Party Transactions and Earnings Management, https://doi.org/10.21632/irjbs.7.1.1-12

Mudambi, R., \& Pedersen, T. (2007). Agency Theory and Resource Dependency Theory: Complementary Explanations for Subsidiary Power in Multinational Corporations

Mustapha, U. A., Nik, N., Rashid, M., Lateef, S. A., \& Bala, A. (2019). The Effect of Corporate Governance Attributes On Audit Quality in Nigeria, (4), 4882-4886.

https://doi.org/10.35940/ijrte.D8313.118419

Oino, I., \& Ukaegbu, B. (2015). The Impact of Capital Structure and Speed up Adjustment: An empirical examination of selected firms in Nigeria, Research in International Business and Finance. 
INTERNATIONAL JOURNAL OF ACADEMIC RESEARCH IN BUSINESS AND SOCIAL SCIENCES

Vol. 10, No. 2, Feb, 2020, E-ISSN: 2222-6990 @ 2020 HRMARS

https://doi.org/10.1016/j.ribaf.2015.03.004

Paiva, I. S., Lourenço, I. C., \& Branco, M. C. (2016). Earnings Management in Family firms: Current state of knowledge and opportunities for future research. Review of Accounting and Finance, 15(1), 85-100. https://doi.org/10.1108/RAF-06-2014-0065

Paiva, I. S., Lourenço, I. C., \& Dias Curto, J. (2018). Earnings Management in Family versus non-family firms: the influence of analyst coverage. Revista Espanola de Financiaciony Contabilidad, 00(00), 1-21. https://doi.org/10.1080/02102412.2018.1463764

Prencipe, A., Bar-Yosef, S., \& Dekker, H. C. (2014). Accounting Research in Family Firms: Theoretical and Empirical Challenges. European Accounting Review, 23(3), 361-385.

https://doi.org/10.1080/09638180.2014.895621

PWC, 2018. (2018). Family Business Survey Nigeria, 2018.

Saleh, N. M., Munir, S., Jaffar, R., \& Yatim, P. (2013). Family ownership, related-party transactions and earnings quality, Asian Academy of Management Journal of Accounting \& Finance

Salvato, C., \& Moores, K. (2010). Research on accounting in family firms: Past accomplishments and future challenges. Family Business Review, 23(3), 193-215. https://doi.org/10.1177/0894486510375069

Sanda, A. U., Garba, T., \& Mikailu, A. S. (2011). Board Independence and Firm Financial Performance : Evidence from Nigeria.

Saona, P., \& Muro, L. (2018). Firm- and Country-Level Attributes as Determinants of Earnings Management: An Analysis for Latin American Firms. Emerging Markets Finance and Trade, 54(12), 2736-2764. https://doi.org/10.1080/1540496X.2017.1410127

Sarkar, J., Sarkar, S., \& Sen, K. (2013). Insider Control, Group Affiliation and Earnings Management in Emerging Economies: Evidence from India. Ssrn. https://doi.org/10.2139/ssrn.2197713

Shin, I. H., Sohn, S. K., \& Park, S. (2019). Related party transactions and income smoothing : new evidence from Korea. Asia-Pacific Journal of Accounting \& Economics, 00(00), 1-18. https://doi.org/10.1080/16081625.2019.1566011

Songini, L., \& Gnan, L. (2015). Family Involvement and Agency Cost Control Mechanisms in Family Small and Medium-Sized Enterprises. Journal of Small Business Management, 53(3), 748-779. https://doi.org/10.1111/jsbm.12085

Tesfaye Lemma, Minga Negash Mlilo, M. (2013). Determinants of earnings management: Evidence from around the world. Journal of Economic Literature, 1-56. https://doi.org/10.2139/ssrn.2370926

Tian, X., Yang, T., \& Yu, T. R. (2018). Real earnings management in family firms: evidence from Chinese listed firms. International Journal of Revenue Management, 10(2), 77-106.

https://doi.org/10.1504/IJRM.2018.091814

Torres-reyna, O. (2007). Panel Data Analysis Fixed and Random Effects using Stata, Princeton University

Villalonga, B., Trujillo, M.-A., Guzmán, A., \& Caceres, N. (2017). What Are Boards For? Evidence from Closely Held Firms in Colombia. Ssrn. https://doi.org/10.2139/ssrn.2989359

wan Nadiah, W. R., \& Mansor, N. (2018). Real Earnings Management in Family Group Affiliation : a research proposal

Wang, D. (2006). Founding family ownership and earnings quality. Journal of Accounting Research, 44(3), 619-656. https://doi.org/10.1111/j.1475-679X.2006.00213.x 
INTERNATIONAL JOURNAL OF ACADEMIC RESEARCH IN BUSINESS AND SOCIAL SCIENCES

Vol. 10, No. 2, Feb, 2020, E-ISSN: 2222-6990 @ 2020 HRMARS

Wang, H., Iglesias, E. M., \& Wooldridge, J. M. (2013). Partial maximum likelihood estimation of spatial

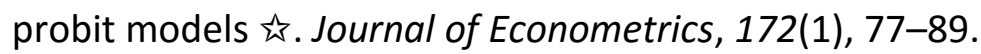
https://doi.org/10.1016/j.jeconom.2012.08.005

Yang, Y. J., Kweh, Q. L., \& Lin, R. C. (2014). Earnings quality of Taiwanese group firms. Asia-Pacific Journal of Accounting and Economics, 21(2), 134-156. https://doi.org/10.1080/16081625.2013.871771 